\title{
Coping strategies used as resources to reduce fear and anxiety caused by oncological treatment: literature review
}

\section{Introduction}

Cancer is a chronic-degenerative disease that is currently becoming more present and can affect any part of the body. The origin of cancer are genetic mutations, 5\% hereditary and 95\% acquired of the environment and life habits. Depending on the state of the disease, the individual can reverse the condition by performing the appropriate treatment of radiotherapy, chemotherapy or surgery, but even with medical care there is still a large number of deaths from this disease. This is why the disease causes feelings of fear and anxiety to shake the person's emotional state. ${ }^{1,2}$

Fear appears when there is evidence that the individual is at risk. Already the challenges that show constant uncertainties about the threat cause anxiety both are linked in the diagnosis of cancer, because the individual deals with dangers and uncertainties in order to contribute to the suffering and/or psychic illness. It is possible to observe that both fear and anxiety are ways of the individual to escape in dangerous situations, and in the case of cancer treatment, both feelings are aggravated, since the disease is feared by its history of death and treatment, which most of the time Weakens the patient. Thus, cancer patients and their families seek strategies to minimize the impact of fear and anxiety resulting from the disease in their lives, in which case coping is characterized. Coping for the oncology area is an important and relevant subject for studies and discussions among psychology professionals. According to the scientific literature, it is effective in the treatment of cancer. Thus, coping strategies consist of behaviors in which people adapt to face adversities and each person needs to have their strategies to face the problem. ${ }^{3}$

\section{Fear, anxiety and palliative care}

The palliative care is the multiprofessional practice that seeks to offer the patient out of possibility of cure a care that integrates all the dimensions of the being, aiming to fulfill a better quality of life for the patient and his family, considering that the consequences caused by the illness cause intense Suffering that affect everyone around the patient. ${ }^{4}$ Fear is a natural feeling of every human being, just as all individuals have the capacity to feel anger, joy, sadness, fear also fits into these emotions because it is a behavior of the body in relation to the stimuli that can threaten The physical and moral integrity of a person. Cancer, for example, is considered an external stimulus, which has been causing suffering in the individual, since the disease threatens the body, the mind, social life, family, among other factors in the life of the patient. ${ }^{5}$ Anxiety, in turn, can be defined as an emotion related to the behavior of assessing risks in the environment. It is evoked in situations in which there is a danger, which may be an unknown situation for the individual or a stimulus that signals danger. When a threatened situation, such as cancer, causes bodily sensations of intense anxiety in an individual, in similar circumstances, the organism may return to the experience of the same bodily sensations. ${ }^{6}$

Fear and anxiety remain close to the diagnosis of cancer, since fear of death and aggressive treatment is expressed in these patients. The diagnosis of diseases such as cancer is associated with the onset
Volume 2 Issue 2 - 2018

\author{
Anna Carolina Chaves Corrêa,' Taís Seleski \\ Maia,' Thayanne Branches Pereira ${ }^{2}$ \\ 'Graduated in psycology, Instituto Esperança De Ensino \\ Superior, Brazil \\ ${ }^{2}$ Mestre e Docente do Curso de Psicologia - Instituto Esperança \\ De Ensino Superior, Brazil
}

Correspondence: Thayanne Branches Pereira, Mestre e Docente do Curso de Psicologia - Instituto Esperança De Ensino Superior, Brazil, Email thaty-branches@hotmail.com

Received: July 20, 2017 | Published: March 09, 2018

of a variety of anxious disorders. Because of this, fear and anxiety are normal feelings expressed by oncology patients, they are ways individuals extravasate what they are feeling, but these in excess end up interfering with the treatment and quality of life of the individual, in some cases leading to pathologies.

\section{Conclusion}

This research used as a method a bibliographical research to collect data on the subject. It was identified in the scientific literature researched in this study, the coping strategies help the patient to face the disease in a way that it can develop self-confidence, self-esteem, capacity to reduce the psychological, physical or social implications experienced, which causes fear reduction and anxiety.

\section{Acknowledgements}

None.

\section{Conflict of interest}

The author declares no conflict of interest.

\section{References}

1. Naoum PC. Sinalização celular do câncer humano. Academia de Ciência e Tecnologia de São José do Rio Preto, Brazil. 2014.

2. Leal Gláucia. Marcas do horror. Revista Mente e cérebro. 2013;43:40.

3. Antoniazzi Adriane Scomazzon,Dell'aglio Débora Dalbosco, Bandeira Denise Ruschel. O conceito de Coping: Uma revisão Teórica. Estud. psicol. 1998;3(2):273-294.

4. Ferreira Ana Paula de Queiroz, Lopes Leany Queiroz Ferreira, Melo Mônica Cristina Batista. O papel do psicólogo na equipe de cuidados paliativos junto ao paciente oncológico. Rev SBPH. 2011;14(2).

5. Piccoli Nathália. De frente com a síndrome do pânico. São Paulo, Brazil: Segredos da Mente; 2016.

6. Graeff FG. Ansiedade, pânico e o eixo hipotálamo-pituitária-adrenal. Rev Bras Psiquiatr. 2007;14(1):233-243. 